\title{
Low Concentrations of PCB (Aroclor 1254) Alter Membrane Bound Ion Dependent ATPases in the Hepatocyte Cells of Mice
}

\author{
Shweta Pathak ${ }^{1}$, Himanshu Pansuria ${ }^{1}$ and Rahul Kundu ${ }^{1}$ \\ ${ }^{1,1,1}$ Department of Biosciences, Saurashtra University, Rajkot-360005, Gujarat State, India
}

\begin{abstract}
Aroclor 1254, a PCB, notwithstanding its banned status, is still available in the environment in low concentration. Reports on its toxic effects on membrane proteins and the mechanism of actions are rare. Therefore, the present study was conducted to investigate the dose and exposure duration dependent effects of low concentration Aroclor 1254 on total, $\mathrm{Na}^{+}, \mathrm{K}^{+}, \mathrm{Ca}^{++}$and $\mathrm{Mg}^{++}$-ATPases on the mouse liver cells. The study tests two hypotheses, (a) the low, environmentally available doses of Aroclor 1254 will cause typical dose and exposure duration dependent responses on the membrane-bound ion dependent ATPases of the hepatic cells and (b) the observed response will be a direct effect of Aroclor on the enzyme protein itself. To check these hypotheses, various groups of mice were exposed to two sublethal doses for three exposure durations of Aroclor 1254. The results indicated no dose dependent effects on the enzymes. However, significant exposure duration dependent changes in membrane bound ATPases were observed. Since the observed changes were mostly enzyme stimulation after subjected to toxication through oral route, the effects of the Aroclor were possibly in the form of indirect oxidative stress through complex chain of reactions exhibited by the cells.
\end{abstract}

Keywords - Aroclor 1254, Hepatic cells, ATPases, Mice.

\section{Introduction}

PCBs are very stable, strongly lipophilic and persistent in the ecosystem. These compounds are generally bio-concentrated through the food chain due to their affinity for lipids and are resistance to metabolism. Some congeners and metabolites of PCBs have a variety of toxicological effects in mammals including hepatotoxicity particularly with chronic exposure [1]. Aroclors, a PCB, are reported to be readily absorbed in soil, remains immobile during leaching process and highly mobile in the presence of organic solvents [2]. Oral $\mathrm{LD}_{50}$ values for Aroclor 1254 are reported to be $1295 \mathrm{mg} / \mathrm{kg} / \mathrm{day}$ in male Osborne-Mendel rats, $1010 \mathrm{mg} / \mathrm{kg} / \mathrm{day}$ in Sherman rats and $4000 \mathrm{mg} / \mathrm{kg} / \mathrm{day}$ in the mink [3]. It has been reported that PCBs show a higher affinity for liver than other adipose tissue when compared to those PCB congeners which have chlorine atoms in ortho positions $[4,5]$. The increased affinity of Aroclor to liver is possibly associated with induction of hepatic binding proteins. All the biological processes associated with the binding proteins or ion channels which are membrane bound proteins. These proteins are excellent indicators to follow the toxic effects of a huge variety of compounds. They show the early signs of life-threatening conditions including chronic degenerative diseases [6]. PCBs generate transient reactive oxygen species as reported by several studies [7]. Membrane bound proteins like ATPases control ion gradients across membranes are particularly susceptible to oxidationinduced changes [8]. It was previously reported that the administration of commercial PCBs, as well as purified isomers to rats inhibited the total ATPase, $\mathrm{Na}^{+}, \mathrm{K}^{+}$-ATPase and $\mathrm{Mg}^{++}$ATPase activity in the fish liver, kidney, and brain tissues of other organisms $[9,10]$. However, most of these studies were conducted using sublethal to near-lethal doses of PCBs. In environment however, PCBs are present in very low amount which may be available to human and other animals through water or food. Going through the literature it was realized that the reports on toxic effects of the PCB in low concentration on the functions of different key enzyme systems in mammalian systems are scanty. It has also been observed that studies on the dose and duration dependent effects of low dose PCB on membrane bound enzyme proteins are rare. Therefore, the present communication was conducted to investigate the low concentration, similar to the environmentally available concentration in the PCB polluted areas, and sub-acute dose and exposure duration dependent effects of Aroclor 1254 on total, $\mathrm{Na}^{+}$, $\mathrm{K}^{+}, \mathrm{Ca}^{++}$and $\mathrm{Mg}^{++}$-ATPases of the mouse liver. The study tested two hypotheses, (a) the low, environmentally available doses of Aroclor 1254 would cause typical dose and exposure duration dependent responses on the membrane-bound ion dependent ATPases of the hepatic cells and (b) the observed response would be a direct effect of Aroclor on the enzyme protein itself.

\section{Materials And Methods}

The PCB used in this study, Aroclor 1254, was procured from Sigma-Aldrich Chemicals Ltd. (CAS No. 11097-69-1). All other chemicals and reagents were of analytical grade and also procured from the Sigma Chemical Co. (St. Louis, MO, USA) for the assay of membrane bound ion-dependent ATPases in liver of mice. Male Swiss albino mice (30-40 g) were kept in the animal house facilities at prescribed conditions as per 
CPCSEA, India. Animals were given commercially available rodent diet and water ad libitum. Different animal groups for the experiments were kept in a standardized conditions $\left(26 \pm 2{ }^{\circ} \mathrm{C} ; 44-55 \% \mathrm{RH}, 10: 14 \mathrm{~h}\right.$ light and dark cycles) for one week before the experiment [11]. All studies were conducted according to the ethical norms approved by the CPCSEA, India (CPCSEA/CH/RF/ACK-2003, 29-07-2003). A total of 63 adult male Swiss albino mice were used for the study. The selection of the doses was based on the available reports of the doses causing non-carcinogenic effects in the liver tissue of mice, especially on the enzymes (acute to sub-acute exposure) [3]. The doses selected therefore, were very low concentrations of Aroclor 1254, comparable to that of a possible human exposure from different environmental sources. Different groups of mice were given oral administration of Aroclor 1254 (0.1 and $1 \mathrm{mg} / \mathrm{kg}$ body weight $/ \mathrm{d}$ ) dissolved in corn oil (vehicle) for three different exposure durations of 4, 8 and 12 days. After completion of toxic exposure, the liver was rapidly removed and washed in ice-cold Sucrose - EDTA - Imidazole buffer (SEI buffer). Known amount of tissue was homogenized using Potter-Elvehjem glass homogenizer to make a $10 \%(\mathrm{w} / \mathrm{v})$ tissue concentration. The tissue preparation and enzyme extraction procedure were as per the method of Zaugg [12] with appropriate modifications. The enzyme extract procedures and the estimation of different membrane bound ion dependent ATPases viz. total-, $\mathrm{Na}^{+}, \mathrm{K}^{+}-, \mathrm{Ca}^{2+}-$ and $\mathrm{Mg}^{2+}$ - ATPases were done as per the method of Zaugg [12] with appropriate modifications $[13,14]$. Inorganic phosphate was measured by the method of Fiske and Subbarow [15]. Total protein content of the tissue extract was estimated by the method of Lowry et al. [16] using crystalline bovine serum albumin as standard. The obtained data were subjected to various statistical analyses for their cumulative acceptability and for testing the hypotheses formulated. Comparison between control and doses were made using one-way ANOVA. A two-way nested ANOVA was done to check the significance in the variations between different doses and amongst different exposure durations. In addition to those tests, Comparison for the significance variations between control and each durations within a given dose were performed using two-tailed Student's 't' test. All statistical procedures were done as per Sokal and Rohlf [17].

\section{Results And Discussion}

In the present study, in vivo dose and duration dependent effects of low concentration Aroclor 1254 on membrane bound ion dependent ATPases was estimated from the hepatic cells of adult male Swiss albino mice. The results showed that activity of total ATPase was inhibited in both the doses $(0.1$ and $1 \mathrm{mg} / \mathrm{kg} / \mathrm{d})$ after 4 and 12 days exposures and more inhibition was observed in $0.1 \mathrm{mg} / \mathrm{kg} / \mathrm{d}$ dose of Aroclor 1254 . However, after 8 days of exposure, a stimulation in the enzyme activity was observed in both the toxicated groups (Fig.1a). Similar trend was observed in activities of $\mathrm{Na}^{+}-\mathrm{K}^{+}$and $\mathrm{Ca}^{++}$ATPases (Fig. 1b \& 1c). In case of $\mathrm{Mg}^{++}$ATPase, the specific activity was inhibited in $0.1 \mathrm{mg} / \mathrm{kg} / \mathrm{d}$ dose after 4 and 12 days exposure. But in higher dose exposed for 4 days, the activity was stimulated. However, after 12 days of exposure the enzyme activity was inhibited. On the other hand, after 8 days of exposure, stimulation was observed in $0.1 \mathrm{mg} / \mathrm{kg} / \mathrm{day}$ dose group followed by inhibition in $1 \mathrm{mg} / \mathrm{kg} / \mathrm{d}$ toxicated group (Fig.1d). The observed effects of Aroclor 1254 was more exposure duration dependent, triggering increased disturbance in the membrane ion channels with increasing time. These alterations were may be due to that exposure of Aroclor 1254 which causes more damage to the permeability and general metabolic activity of the hepatic cell. It is also possible that the imposed stress by the PCB was affecting the cellular transmembrane movement and cell tried to stabilize it by enhancing or inhibiting the ion channels.

\section{(a) TOTAL ATPase}

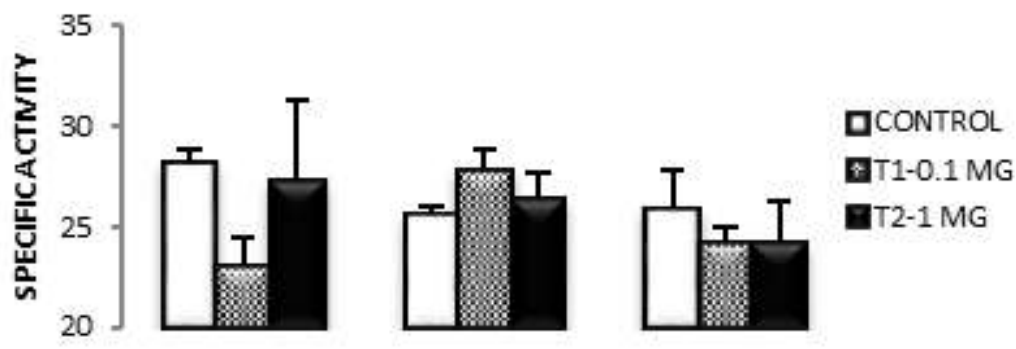




\section{(b) $\mathrm{Na}^{+}-\mathrm{K}^{+}$ATPase}
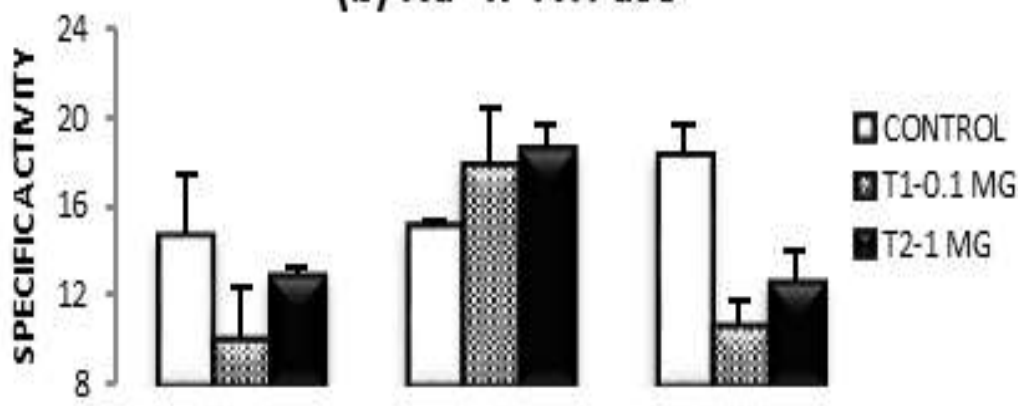

(c) $\mathrm{Ca}^{++}$ATPase
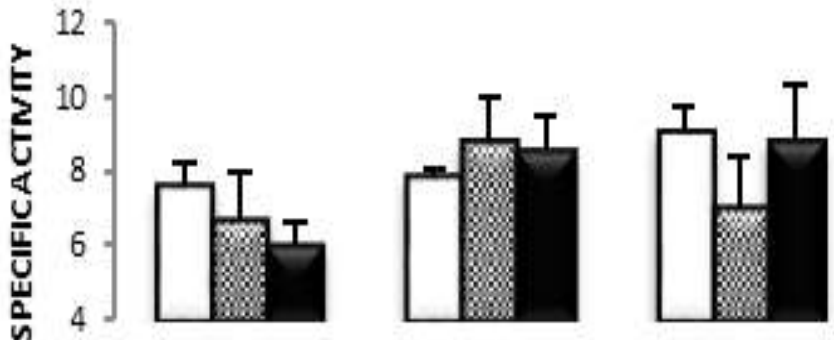

口CONTROL

분T1-0.1 MG

由T2-1MG

\section{(d) $\mathrm{Mg}^{++}$ATPase}

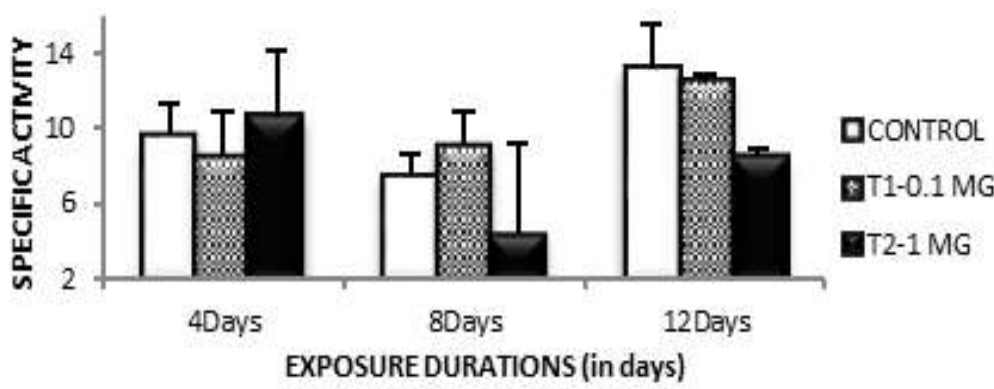

Fig. 1. Dose and duration dependent changes in the specific activities of different ATPases after Aroclor 1254 intoxication. The error bars represents the standard deviation and ' $*$ ' sign represents the significant variations at $\mathrm{P}=0.05$ level.

Liver, being the largest gland and main detoxifying organ of the body is a principal location for accumulation of absorbed toxicants. Liver damage is one of the clear signs of PCB poisoning in humans. Since the ATPases are responsible for trans-membrane movements of ions, it is possible that the Aroclor affected the transport channels of the liver cells by altering the enzyme activity [4]. The results of two-factor ANOVA showed a predominantly exposure duration dependent effects of Aroclor (Table 1). However, the Student's t-test performed between the control and toxicated groups showed variations in different enzymes studied in liver tissue. In case of total ATPase, significant variations were observed in 4 and 8 days of exposure durations between control and lowest dose but no significance was observed in higher dose in most of the enzymes studied (Table 2). The results of the single-factor ANOVA showed high significant variations between the exposure durations in most of the enzymes studied (Table 3), possibly governed by a predominantly exposure duration dependent effects [13].

Table-1. Result of Two-Factor ANOVA between control and toxicated groups.

\begin{tabular}{|c|c|c|c|c|}
\hline Sources of Variation & TOTAL & $\mathbf{N a}^{+}-\mathbf{K}^{+}$ & $\mathbf{C a}^{++}$ & $\mathbf{M g}^{++}$ \\
\hline Amongst doses & 0.91 & $5.85^{*}$ & $5.21^{*}$ & $13.62^{*}$ \\
\hline Within durations & $3.75^{*}$ & $22.61^{*}$ & $6.44^{*}$ & $10.82^{*}$ \\
\hline
\end{tabular}

* Significant at $\mathrm{P}=0.05(F$ crit $(d f=3,8)=3.01)$

** Significant at $\mathrm{P}=0.05(F$ crit $(d f=8,35)=2.36)$ 
Table-2. Result of t-test between control and individual exposure duration within each dose.

\begin{tabular}{|c|c|c|c|c|c|c|c|c|}
\hline & \multicolumn{2}{|c|}{ TOTAL } & \multicolumn{2}{c|}{$\mathbf{N a}^{+}-\mathbf{K}^{+}$} & \multicolumn{2}{c|}{$\mathbf{C a}^{++}$} & \multicolumn{2}{c|}{$\mathbf{M g}^{++}$} \\
\hline & $0.1 \mathrm{mg}$ & $1 \mathrm{mg}$ & $0.1 \mathrm{mg}$ & $1 \mathrm{mg}$ & $0.1 \mathrm{mg}$ & $1 \mathrm{mg}$ & $0.1 \mathrm{mg}$ & $1 \mathrm{mg}$ \\
\hline 4 days & $13.12^{*}$ & 0.86 & $3.27^{*}$ & 1.13 & $2.83^{*}$ & $3.44^{*}$ & 1.03 & 0.70 \\
\hline 8 days & $2.74^{*}$ & 1.10 & 1.52 & $2.77^{*}$ & 1.09 & 0.71 & 1.09 & $2.52^{*}$ \\
\hline 12 days & 0.77 & 0.73 & $14.74^{*}$ & $8.07^{*}$ & $3.69^{*}$ & 0.34 & 0.24 & $2.60^{*}$ \\
\hline
\end{tabular}

$*$ Significant at $\mathrm{P}=0.05($ T crit. $=2.447)$

Table -3. Result of Single factor ANOVA between individual exposure durations within each group.

\begin{tabular}{|c|c|c|c|c|}
\hline & TOTAL & $\mathbf{N a}^{+}-\mathbf{K}^{+}$ & $\mathbf{C a}^{++}$ & $\mathbf{M g}^{++}$ \\
\hline CONTROL & 1.31 & 3.53 & 3.24 & $4.53^{*}$ \\
\hline $\mathbf{0 . 1} \mathbf{~ m g}$ & $28.47^{*}$ & $29.00^{*}$ & $6.60^{*}$ & 1.98 \\
\hline $\mathbf{1 ~ m g}$ & 3.61 & $27.96^{*}$ & $5.86^{*}$ & $19.38^{*}$ \\
\hline
\end{tabular}

*Significant at $\mathrm{P}=0.05(F$ crit. $=4.26)$

The results of the present study obviously answer the first hypotheses as predominantly exposure duration dependent effects. The use of unpurified enzyme preparation prohibits the unequivocal determination of the mechanism involved in activity, these compounds are not specific effects for one type of ATPase suggested the possibility that more than one factor might have been involved. The result of the study suggests the more complex indirect chain of events therein answers the second hypotheses [14]. Some studies showed that PCBsinduced toxic manifestations are associated with the production of reactive oxygen species [18]. Hassoun et al. [19] reported that polychlorinated biphenyl 126 induces reactive oxygen species in brain and liver of experimental rats. The reactive oxygen species may propagate the initial attack on lipid membranes of the brain to cause lipid peroxidation [20]. Therefore, one of the possibilities of indirect effect of Aroclor 1254 is oxidative stress which may alter the activity of membrane bound ion dependent ATPases by producing free radicals. It may also be possible that PCBs accumulated in the intracellular space and alter the activity of membrane bound ion-dependent ATPases which altered the membrane permeability [21- 24].

\section{Conclusion}

In conclusion, the present study revealed a predominantly exposure duration dependent effects of the Aroclor 1254 on the membrane bound ion dependent ATPases in the hepatic cells of mice. However, the disturbance in the ATPases activity was caused by exposure durations is clearly indicative of some indirect effects of PCB in in vivo conditions. It may be possible that oxidative stress might have played a role in the alteration in the activity of ATPases which possibly have altered the channel protein configurations in the plasma membrane of the hepatic cells.

\section{Acknowledgments}

Authors are thankful to UGC, Govt. of India, New Delhi for supporting this study through its DSA / CAS Programme. UGC is also thankfully acknowledged for a Meritorious Research Fellowship awarded to the senior author.

\section{References}

[1.] L.G. Hansen, Halogenated aromatic compounds. In: Cockerham LG, Shane BS, eds. Basic Environ. Toxicol. Ann. Arbor. Mich : CRC Press.. 1994,199-230.

[2.] USAF, The Installation Restoration Program Toxicology Guide. Volume 3. Aerospace Medical Division, Air Force Systems Command, Wright-Patterson Air Force Base, Ohio,1989 pp. 52-1-52-68.

[3.] ATSDR, Toxicological Profile for Polychlorinated Biphenyls. Draft for Public Comment (Update). Prepared by Research Triangle Institute, under Contract No. 205-93-0606 for ATSDR, Public Health Service, U.S. Department of Health and Human Services, 1995.

[4.] H. Yoshimura et al., Inductive effect on hepatic enzymes and toxicity of congeners of PCBs and PCDFs, Environ. Health Perspect. $59,1985,113-119$.

[5.] A.P.JM. Van Birgelen et al., Toxic potency of 3,3',4,4',5-pentachlorobiphenyl relative to and in combination with 2,3,7,8tetrachlorodibenzo-p-dioxin in a subchronic feeding study in the rat, Toxicol. Appl. Pharmacol. 127, 1994, 209-211.

[6.] Iván Restrepo-Angulo, Andrea De Vizcaya-Ruiz and Javier Camachoa, Ion channels in toxicology, J. Appl. Toxicol. 2010 DOI $10.1002 /$ jat.1556

[7.] E. Mariussen, O. Myhre, T. Reistad, F. Fonnum, The polychlorinated biphenyl mixture Aroclor 1254 induces cell death of rat cerebellar granule cells: the involvement of the $\mathrm{N}$-methyl-daspartate receptor and reactive oxygen species, Toxicol. Appl. Pharmacol. 179, 2002, 137-44.

[8.] N. Sridevi, P. Venkataraman, K. Senthilkumar, G. Krishnamoorthy, J. Arunakaran, Oxidative stress modulates membrane bound ATPases in brain regions of PCB (Aroclor 1254) exposed rats: protective role of $\alpha$-tocopherol. Biomed. Pharmacother. 61, 2007, $435-40$. 
[9.] R.B. Koch, Polychlorinated biphenyls. Effect of long-term exposure on ATPase activity in fish, Pimephales promelas, Bull. Environ. Contam. Toxicol. 7, 1972, 87.

[10.] R. Hale, M. Alaee, J. Manchester-Neesvig, H. Stapleton, M. Ikonomou, Polybrominated diphenyl ether flame retardants in the North American Environment, Env. Int. 29, 2003, 771-779.

[11.] L.F.M. Van Zutphen, V. Baumans, A.C. Beyners, Principles of Laboratory Animals Science, 1993.

[12.] W.S. Zaugg, A simplified preparation for ATPase determination in gill tissue, Can. J. Fish Aquatic Sci. 39 (1),1982, $215-217$.

[13.] R. Lakshmi, R. Kundu, E. Thomas, A.P. Mansuri, Mercuric chloride induced inhibition of different ATPases in the intestine of mudskipper, Boleophthalmus dentatus. Ecotox. Env. Safety 21 (1), 1991, $121-125$.

[14.] S. Pathak, R. Kundu, Short-term PCB (Aroclor 1254) toxicity on few phosphatases in mice brain, Dose Response, 2011, DOI: 10.2203/dose-response.10-037.Kundu.

[15.] C.F. Fiske, Y. Subbarow, The colorimetric determination of phosphorus, J. Biol. Chem. 66, 1925, 375-400.

[16.] O.H. Lowry, N.J. Rosebrough, A.L. Farr, R.J. Randall, Protein measurement with the Folin-phenol reagent, J. Biol. Chem. 193, 1951, 265-275.

[17.] R.R. Sokal, F.J. Rohlf, Biometry. W.H. Freeman and Company, San Francisco, 1969, pp.260.

[18.] J.C. Tharappel, E.Y. Lee, L.W. Robertson, B.T. Spear, H.P. Glanet, Regulation of cell proliferation, apoptosis and transcriptional activities during the promotion of liver carcinogenesis by PCB, Toxicol. Appl. Pharmacol. 179, 2002, $172-84$.

[19.] E.A. Hassoun, H. Wang, A. Abushaban, Induction of oxidative stress in the tissues of rats after chronic exposure to TCDD, 2,3,4,7,8-Pentachlorodibenzofuran and 3,3',4,4',5-Pentachlorobiphenyl. J. Toxicol. Environ. Health, 65, $2002,825-42$.

[20.] M. Das, S.K. Kanna, Clinico epidemiological and toxicological and safety evaluation studies on argensone oil. Crit. Rev. Toxicol. 27, 1997, 273-97.

[21.] J. Jigyasi, R. Kundu, Low dose TCDD affects membrane bound ion dependent ATPases in mice liver, IOSR Jour. Env. Sci. Tox. Food Tech. 2 ,2013, 15-19.

[22] J. Thaker, J. Chhaya, S. Nuzhat, R. Mitral, A.P. Mansuri, R. Kundu, Effects of Chromium (VI) on some ion dependent ATPases in gills, kidney and intestine of a coastal teleost, Periophthalmus dipes. Toxicology, 112, 1996, 237-244.

[23] R. Kundu, R. Lakshmi, A.P. Mansuri, The entry of mercury through the membrane: An enzymological study using a tolerant fish Boleophthalmus dentate. Proceedings of the Academic Environmental Biology 1,1992, 1-6.

[24] J. Jigyasi, R. Kundu, Effects of Low Dose Dioxin on Membrane Bound Ion Dependent ATPases in Mice Kidney. IOSR Jour. Env. Sci. Tox. Food Tech. 2 ,2013, 43-48. 